\title{
Isolation of Scalarane-Type Sesterterpenoids from the Marine Sponge Dysidea sp. and Stereochemical Reassignment of 12-epi-Phyllactone D/E
}

\author{
A-Young Shin ${ }^{1,2} \mathbb{D}$, Arang Son ${ }^{3}$, Changhoon Choi ${ }^{3} \mathbb{C}$ and Jihoon Lee ${ }^{1,2, * \mathbb{C}}$ \\ 1 Korea Institute of Ocean Science \& Technology (KIOST), Busan 49111, Korea; dkdud1624@kiost.ac.kr \\ 2 Department of Marine Biotechnology, University of Science \& Technology, Daejeon 34113, Korea \\ 3 Department of Radiation Oncology, Samsung Medical Center, Seoul 06351, Korea; arang.son@sbri.co.kr (A.S.); \\ changhoon1.choi@samsung.com (C.C.) \\ * Correspondence: jihoonlee@kiost.ac.kr; Tel.: +82-51-664-3343
}

Citation: Shin, A.-Y.; Son, A.; Choi, C.; Lee, J. Isolation of Scalarane-Type Sesterterpenoids from the Marine Sponge Dysidea sp. and Stereochemical Reassignment of 12-epi-Phyllactone D/E. Mar. Drugs 2021, 19, 627. https://doi.org/ $10.3390 / \mathrm{md} 19110627$

Academic Editor: Vassilios Roussis

Received: 12 October 2021

Accepted: 8 November 2021

Published: 9 November 2021

Publisher's Note: MDPI stays neutral with regard to jurisdictional claims in published maps and institutional affiliations.

Copyright: ( $\odot 2021$ by the authors Licensee MDPI, Basel, Switzerland. This article is an open access article distributed under the terms and conditions of the Creative Commons Attribution (CC BY) license (https:// creativecommons.org/licenses/by/ $4.0 /)$.

\begin{abstract}
The chemical investigation of the marine sponge Dysidea sp., which was collected from Bohol province in the Philippines, resulted in the identification of 15 new scalarane-type sesterterpenoids $(\mathbf{1}-14,16)$, together with 15 known compounds. The chemical structures of the new compounds were elucidated based on NMR spectroscopy and HRMS. The structure of 12-epi-phyllactone D/E (15) isolated during this study was originally identified in 2007. However, careful inspection of our experimental ${ }^{13} \mathrm{C}$ NMR spectrum revealed considerable discrepancies with the reported data at C-9, C-12, C-14, and C-23, leading to the correction of the reported compound to the C-12 epimer of 15, phyllactone D/E. The biological properties of compounds 1-16 were evaluated using the MDA-MB-231 cancer cell line. Compound 7, which bears a pentenone E-ring, exhibits significant cytotoxicity with a $\mathrm{GI}_{50}$ value of $4.21 \mu \mathrm{M}$.
\end{abstract}

Keywords: Dysidea; sesterterpenoid; scalarane; marine sponge; marine natural product; anticancer activity; stereochemistry reassignment

\section{Introduction}

Sesterterpenoids, such as the ophiobolins, sterigmatocystin, and hippolide A, have attracted a lot of attentions as potent pharmaceutical compounds because of their unique anti-inflammatory activity and cytotoxicity in various cancer cell lines [1]. These compounds are ubiquitous in a broad range of natural sources, from easily accessible terrestrial plants and insects to hard-to-access marine organisms. In marine nature, the scalarane-type scaffolds have emerged as one of the most prevalent structural features of the sesterterpenoids [2]. Since scalarin, a pentacyclic scalarane, was first isolated from the marine sponge Cacospongia scalaris in 1972 [3], a number of scalarane-type sesterterpenoids has been isolated from Dysidea sp. [4,5], Phyllospongia sp. [6-11], Strepsichordaia sp. [12], Cateriospongia sp. [13,14], Smenospongia sp. [15], and Hyrtios sp. [16], belonging to the order Dictyoceratida [17].

This family of scalarane derivatives is featured with a trans-fused 6/6/6/6 ring system and can be further categorized into three structural subgroups, namely scalarane, homoscalarane, and bishomoscalarane, based on the presence of single carbon substituents at C-20 and/or C-24 (Figure 1). Among them, bishomoscalarane exhibits an exceptionally broad range of diversity in the carbon framework, arising from two distinctive sites: C-20 and C-24/C-25 (Figure 2). Therefore, cyclopropane or alcohol/esters are frequently found at C-20 adjacent to the A ring [12]. The oxidation of C-24 and C-25 results in the formation of an extra E ring in the form of a lactone or cyclopentenone [18]; 24-oxo-25-norbishomoscalarane has also been identified as another feature of the D ring [8]. In addition, oxidation of the backbone usually occurs at C-3 [6], C-12 [19], and C-16 [12] to produce 
hydroxyl or ester substituents. A large group of bishomoscalarane derivatives found in nature is considered to be the outcome of these variations occurring in combinations.

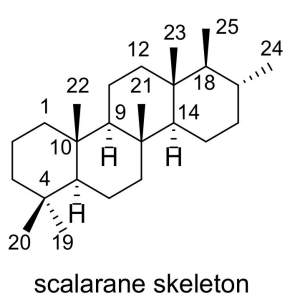

Figure 1. Subtypes of the scalarane skeleton found in marine nature.
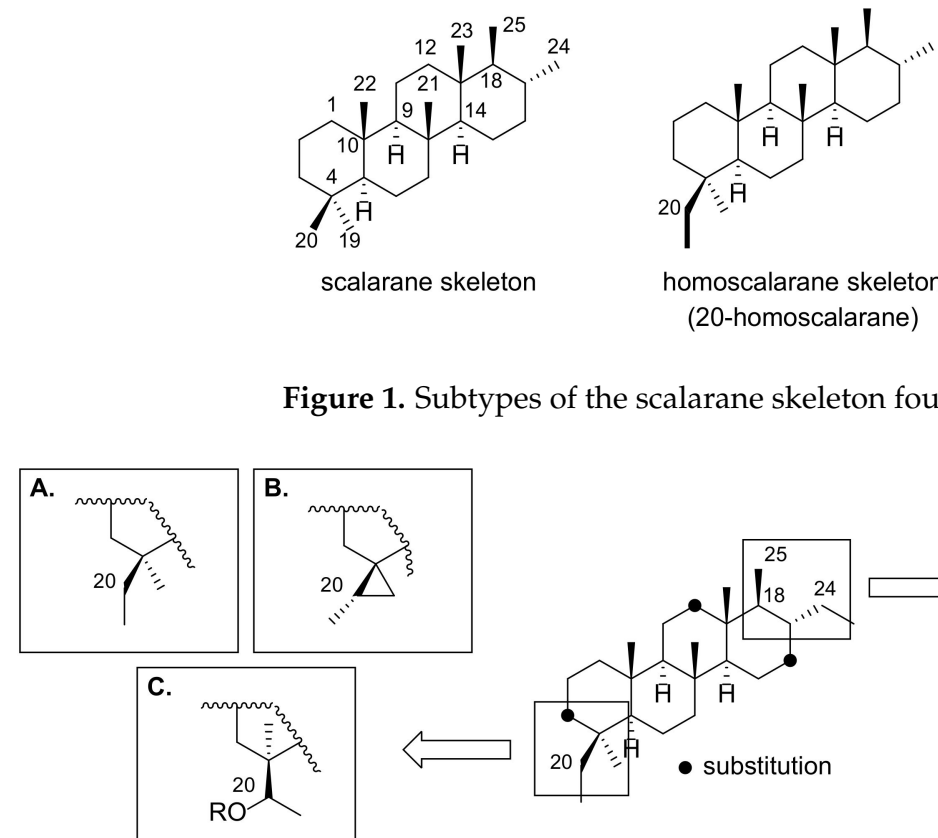

homoscalarane skeleton

(20-homoscalarane)

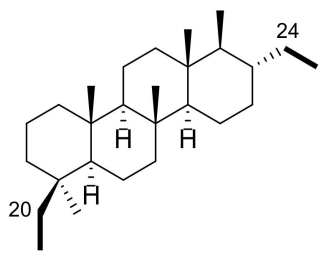

bishomoscalarane skeleton (20,24-bishomoscalarane)

$\mathrm{R}=\mathrm{H}$ or $\mathrm{Ac}$ or propionyl

\begin{tabular}{cclc} 
compound & skeleton & compound & skeleton \\
\hline honulactones & $\mathrm{B}+\mathrm{D} / \mathrm{C}+\mathrm{D}$ & $\begin{array}{l}\text { phyllolactones } \\
\text { phyllactones } \\
\text { phyllofolactones }\end{array}$ & $\mathrm{A}+\mathrm{D}$ \\
cateriofenones & $\mathrm{A}+\mathrm{D} / \mathrm{A}+\mathrm{E} / \mathrm{A}+\mathrm{F}$ & \\
phyllofenones & $\mathrm{A}+\mathrm{E} / \mathrm{A}+\mathrm{F}$ & &
\end{tabular}

Figure 2. Diversity of bishomoscalarane skeletons frequently found in nature.

The marine sponge Dysidea sp. is known to be a rich source of scalaranes, which exhibits useful pharmacological properties, such as anticancer and antimicrobial activities $[17,20-24]$. In the course of our studies on bioactive natural products from marine organisms, we inspected the chemical components of Dysidea sp. collected from the Bohol province in the Philippines. As a result, we identified 15 new scalarane derivatives, including one scalarane, four 20,24-bishomo-25-norscalaranes, and 10 bishomoscalaranes (Figure 3), along with 14 known compounds (Figure S1, Supplementary Materials). In this report, we disclose the structural assignment of the new scalarane sesterterpenoids and their pharmacological properties as anti-cancer agents. In addition, the C-12 configuration of compound 15, which was assigned by Li in 2007 [11], was reinvestigated because of the significant differences observed between the reported and experimental ${ }^{13} \mathrm{C}$ chemical shifts at C-9, C-12, C-14, and C-23. 

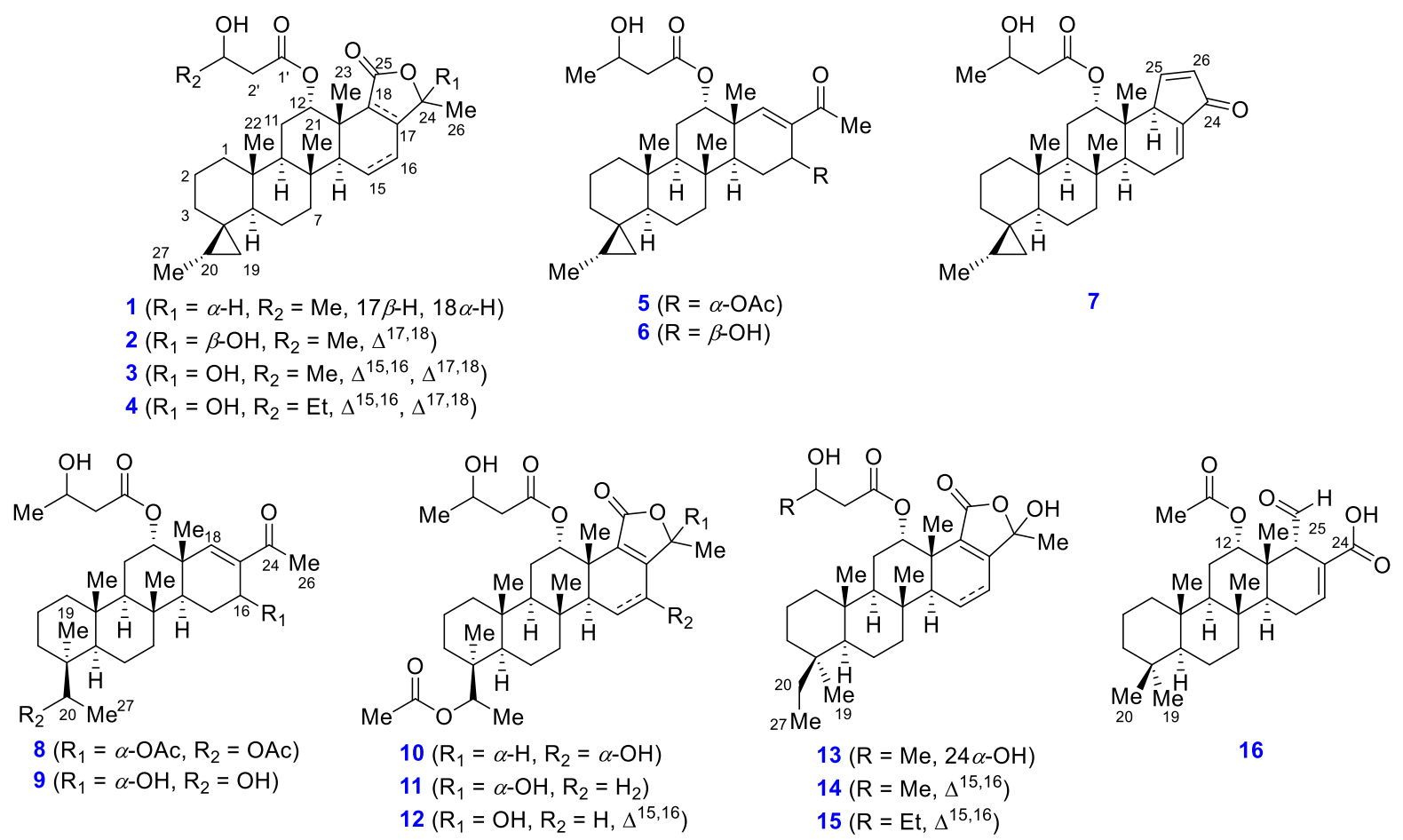

Figure 3. The structures of compounds 1-16 isolated from Dysidea sp.

\section{Results and Discussion}

\subsection{Structure Elucidation}

Compound 1 was isolated as a colorless oil, and its molecular formula was determined to be $\mathrm{C}_{31} \mathrm{H}_{48} \mathrm{O}_{5}$ using HRESIMS ( $m / z[\mathrm{M}+\mathrm{Na}]^{+}$523.3382, calcd 523.3394), corresponding to eight degrees of unsaturation (DOU). The ${ }^{1} \mathrm{H}$ NMR spectrum of 1 exhibited three singlet methyl groups at $\delta_{\mathrm{H}} 0.77,0.82$, and 1.04; three doublet methyl groups at $\delta_{\mathrm{H}} 1.07,1.23$, and 1.37; and three oxymethines at $\delta_{\mathrm{H}} 4.03,4.19$, and 5.41. Furthermore, unique upfield signals at $\delta_{\mathrm{H}} 0.57$ and -0.49 indicated the presence of a cyclopropane. Analysis of the ${ }^{13} \mathrm{C}$ NMR and HSQC spectra revealed the presence of two ester carbons $\left(\delta_{\mathrm{C}} 174.8\right.$ and 171.7), three oxymethine carbons $\left(\delta_{\mathrm{C}} 80.4,74.8,64.5\right), 10$ methylene carbons, six methine carbons, and six methyl groups. The HMBC data showed notable correlations between the singlet methyl groups and methines from $\delta_{\mathrm{H}} 0.77$ to $\delta_{\mathrm{C}} 51.4 / 50.3, \delta_{\mathrm{H}} 0.82$ to $\delta_{\mathrm{C}} 54.3 / 51.4$, and $\delta_{\mathrm{H}} 1.04$ to $\delta_{\mathrm{C}} 54.3$, which are known as characteristic correlations occurring from the ring junctions of scalarane-type 6/6/6/6 fused-cyclic systems (Figure 4). Additional HMBC correlations from the doublet methyl group at $\delta_{\mathrm{H}} 1.37$ to $\delta_{\mathrm{C}} 80.4 / 44.9$ and from the methine at $\delta_{\mathrm{H}} 2.34$ to $\delta_{\mathrm{C}} 174.8 / 44.9$ suggested the existence of a $\gamma$-valerolactone moiety. Therefore, our preliminary findings led to the hypothesis that compound $\mathbf{1}$ possessed a honulactone A-like scaffold (B+D type shown in Figure 2) [12].
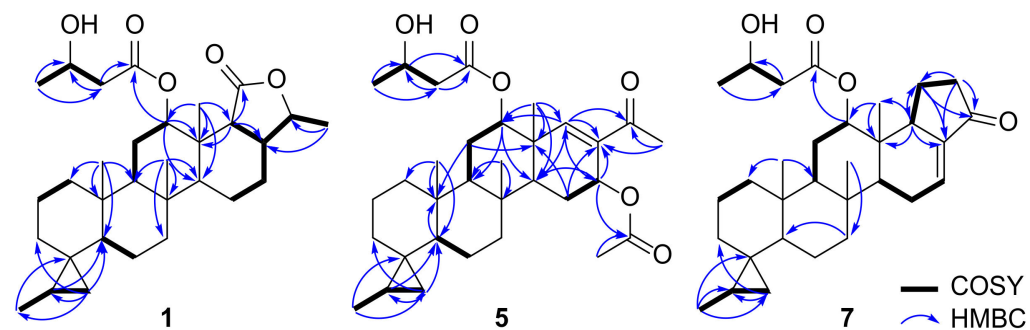

Figure 4. COSY and HMBC correlations observed for compounds 1, 5, and $\mathbf{7 .}$ 
While the $\triangle^{17,18}$-olefin in honulactones is considered one of the structural features that forms the unsaturated lactone E-ring, the initially identified $\gamma$-valerolactone and DOU suggest the possibility of a saturated terminal lactone in compound $\mathbf{1}$. This speculation was confirmed by the ${ }^{1} \mathrm{H}-{ }^{1} \mathrm{H}$ COSY cross peak observed for $\mathrm{H}_{2}-15-\mathrm{H}_{2}-16-\mathrm{H}-17-\mathrm{H}-18$, as well as $\mathrm{HMBC}$ correlations from $\mathrm{CH}_{3}-23\left(\delta_{\mathrm{H}} 1.04\right)$ to $\mathrm{C}-18\left(\delta_{\mathrm{C}} 52.5\right)$ and from $\mathrm{H}-18\left(\delta_{\mathrm{H}} 2.34\right)$ to $\mathrm{C}-13\left(\delta_{\mathrm{C}} 38.7\right)$. In addition, the cyclopropane moiety inferred from the ${ }^{1} \mathrm{H}$ NMR data was positioned at C-4 based on the HMBC correlations from $\mathrm{H}_{2}-19\left(\delta_{\mathrm{H}} 0.57\right.$, and -0.49$)$ to C-3 $\left(\delta_{\mathrm{C}} 33.2\right) / \mathrm{C}-5\left(\delta_{\mathrm{C}} 50.3\right)$ and from $\mathrm{CH}_{3}-27\left(\delta_{\mathrm{H}} 1.07\right)$ to $\mathrm{C}-4\left(\delta_{\mathrm{C}} 22.7\right)$, and the spin system for $\mathrm{CH}_{3}-27-\mathrm{H}-20\left(\delta_{\mathrm{H}} 0.72\right)-\mathrm{H}_{2}-19\left(\delta_{\mathrm{H}} 0.57,-0.49\right)$ in the ${ }^{1} \mathrm{H}-{ }^{1} \mathrm{H}$ COSY spectrum. Interpretation of the remaining $\mathrm{HMBC}$ correlations from $\mathrm{CH}_{3}-4^{\prime}\left(\delta_{\mathrm{H}} 1.23\right)$ to $\mathrm{C}-2^{\prime}\left(\delta_{\mathrm{C}} 43.3\right) / \mathrm{C}-3^{\prime}\left(\delta_{\mathrm{C}} 64.5\right)$, $\mathrm{H}_{2}-2^{\prime}\left(\delta_{\mathrm{H}} 2.49 / 2.42\right)$ to $\mathrm{C}-1^{\prime}\left(\delta_{\mathrm{C}} 171.7\right) / \mathrm{C}-3^{\prime}$, and $\mathrm{H}-12\left(\delta_{\mathrm{H}} 5.41\right)$ to $\mathrm{C}-1^{\prime}$ elucidated the 3-hydroxyl butanoate group at C-12.

The trans-fused cyclic scaffold in $\mathbf{1}$ was determined from the NOESY cross peaks observed between $\mathrm{H}-11 \beta\left(\delta_{\mathrm{H}} 1.71\right)$ and $\mathrm{CH}_{3}-21\left(\delta_{\mathrm{H}} 0.82\right) / \mathrm{CH}_{3}-22\left(\delta_{\mathrm{H}} 0.77\right)$, and $\mathrm{CH}_{3}-23$ and $\mathrm{CH}_{3}-21 / \mathrm{H}-17\left(\delta_{\mathrm{H}} 1.86\right)$ (Figure 5). The NOESY correlations between $\mathrm{H}-12$ and $\mathrm{CH}_{3}-23$, and $\mathrm{H}-18$ and $\mathrm{H}-14\left(\delta_{\mathrm{H}} 1.23\right) / \mathrm{H}-24\left(\delta_{\mathrm{H}} 4.03\right)$ suggested the $\beta$-orientations of $\mathrm{H}-12$ and $\mathrm{CH}_{3}-26$, respectively. Moreover, the $20 S^{*}$ configuration of $\mathrm{CH}_{3}-27$ was determined based on the NOESY signals observed between $\mathrm{H}-19_{\text {cis }}\left(\delta_{\mathrm{H}}-0.49\right)$ and $\mathrm{H}-3 \beta\left(\delta_{\mathrm{H}} 1.24\right) / \mathrm{CH}_{3}-27$, and $\mathrm{H}-19_{\text {trans }}\left(\delta_{\mathrm{H}} 0.57\right)$ and $\mathrm{H}_{2}-6$.

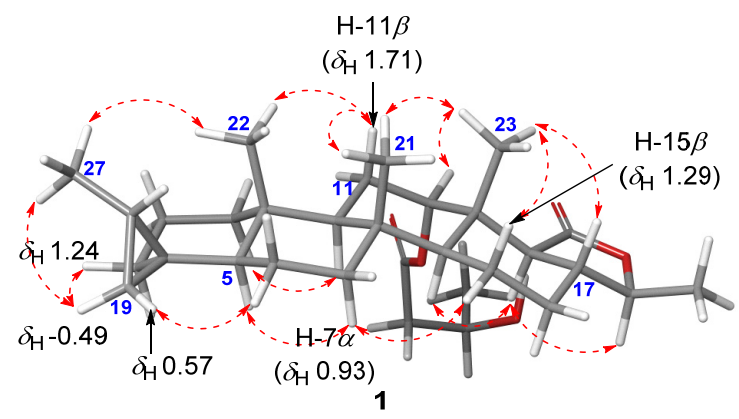

Figure 5. NOESY correlations observed for compound 1.

Compound 2 was isolated as a colorless oil, and its molecular formula was determined to be $\mathrm{C}_{31} \mathrm{H}_{46} \mathrm{O}_{6}$ by HRESIMS ( $m / z[\mathrm{M}+\mathrm{Na}]^{+}$537.3167, calcd 537.3187), corresponding to nine degrees of unsaturation. Analysis of the 1D and 2D NMR spectra obtained for 2 indicated a similar carbon framework to 1 , but the higher oxidation state of the lactone in $\mathrm{E}$ ring appeared as a major difference. $\mathrm{HMBC}$ correlations from $\mathrm{CH}_{3}-23\left(\delta_{\mathrm{H}} 1.22\right)$ to $\mathrm{C}-18\left(\delta_{\mathrm{C}}\right.$ 133.7) and from $\mathrm{CH}_{3}-26\left(\delta_{\mathrm{H}} 1.56\right)$ to $\mathrm{C}-17\left(\delta_{\mathrm{C}} 162.9\right)$ revealed an $\alpha, \beta$-unsaturated lactone in the E ring, which was responsible for the one degree higher DOU than that of 1 . In addition, the ${ }^{13} \mathrm{C}$ chemical shift of C-24 $\left(\delta_{\mathrm{C}} 104.4\right)$ was characteristic of a ketal carbon atom, of which the position was confirmed by $\mathrm{HMBC}$ correlations from $\mathrm{CH}_{3}-26$ to $\mathrm{C}-24$. The $\beta$-configuration of $\mathrm{OH}-24$ was determined by the NOESY correlation observed between $\mathrm{H}-16 \alpha\left(\delta_{\mathrm{H}} 2.28\right)$ and $\mathrm{CH}_{3}-26$ (Figure S3, Supplementary Materials).

Compound 3 was isolated as a mixture of two inseparable epimers. The molecular formula of 3 was deduced to be $\mathrm{C}_{31} \mathrm{H}_{44} \mathrm{O}_{6}$ by HRESIMS $(\mathrm{m} / z \text { [M }+\mathrm{Na}]^{+}$535.3011, calcd 535.3030), corresponding to 10 degrees of unsaturation. An initial inspection of the ${ }^{13} \mathrm{C}$ NMR spectrum revealed that most of the peaks were split into a doublet-like shape, indicating a 1:1 mixture of diastereomers. The 1D and 2D NMR spectra obtained for compound 3 exhibited most of the structural features of 2, except for one more disubstituted olefin observed at $\delta_{\mathrm{H}}(6.38 / 6.37) / \delta_{\mathrm{C}}(138.84 / 138.80)$ and $\delta_{\mathrm{H}}(6.29 / 6.25) / \delta_{\mathrm{C}}(118.6 / 118.4)$. The location of the double bond was determined to be $\triangle^{15,16}$ using the consecutive ${ }^{1} \mathrm{H}$ ${ }^{1} \mathrm{H}$ COSY correlations observed for $\mathrm{H}-14\left(\delta_{\mathrm{H}} 2.69 / 2.62\right)-\mathrm{H}-15\left(\delta_{\mathrm{H}} 6.38 / 6.37\right)-\mathrm{H}-16\left(\delta_{\mathrm{H}}\right.$ 6.29/6.25). The splittings observed in the ${ }^{13} \mathrm{C}$ NMR spectrum were most prominent at $\mathrm{CH}_{3}-26\left(\Delta \delta_{\mathrm{C}} 1.13 \mathrm{ppm}\right)$, informing a mixture of $\mathrm{C}-24$ epimers. This phenomenon has often been observed in the case of 24-homoscalaranes, which possess both an $\triangle^{15,16}$ 
olefin and 24-hydroxy pentenolide E-ring $[25,26]$. Since the $\triangle^{15,16}$-olefin increases the planarity of the D-ring and renders the C-24 stereocenter more isolated, the $24 R^{*}$ and $24 S^{*}$ diastereomers exhibit almost identical spectroscopic and chromatographic behaviors to give an inseparable mixture.

Compound 4 was isolated as an inseparable mixture and its molecular formula was determined to be $\mathrm{C}_{32} \mathrm{H}_{46} \mathrm{O}_{6}$ by HRESIMS $\left(m / z[\mathrm{M}+\mathrm{Na}]^{+} 549.3163\right.$, calcd 549.3187), indicating 10 degrees of unsaturation. The NMR spectra of 4 were only discriminated from those of 3 by the extra methylene group observed at $\delta_{\mathrm{H}} 1.50$ and $\delta_{\mathrm{C}} 29.5 / 29.4$, which was also supported by the mass difference of +14 . The extra methylene group was observed in the ester side chain located at $\mathrm{C}-12$, which formed a 3-hydroxypentanoate moiety, as supported by the spin system for $\mathrm{H}_{2}-2^{\prime}\left(\delta_{\mathrm{H}} 2.35\right)-\mathrm{H}-3^{\prime}\left(\delta_{\mathrm{H}} 3.90 / 3.86\right)-\mathrm{H}_{2}-4^{\prime}\left(\delta_{\mathrm{H}} 1.50\right)-\mathrm{CH}_{3}-5^{\prime}\left(\delta_{\mathrm{H}} 0.95\right)$ in the ${ }^{1} \mathrm{H}-{ }^{1} \mathrm{H}$ COSY spectrum.

Compound 5 was isolated as a colorless oil. Its molecular formula was determined to be $\mathrm{C}_{32} \mathrm{H}_{48} \mathrm{O}_{6}$ by HRESIMS ( $m / z[\mathrm{M}+\mathrm{Na}]^{+} 551.3310$, calcd 551.3343), corresponding to nine degrees of unsaturation. Our initial analysis of the ${ }^{1} \mathrm{H}$ NMR spectrum obtained for compound $\mathbf{5}$ indicated the presence of the scalarane-type scaffold: five singlet methyl groups at $\delta_{\mathrm{H}} 0.80,0.84,1.06,2.02$, and 2.22; two doublet methyl groups at $\delta_{\mathrm{H}} 1.08$ and 1.25; three oxymethines at $\delta_{\mathrm{H}} 4.19,5.11$, and 5.76; unique cyclopropane signals at $\delta_{\mathrm{H}} 0.59$ and -0.49 ; and one singlet olefin at $\delta_{\mathrm{H}} 6.72$. The ${ }^{13} \mathrm{C}$ NMR and HSQC spectra showed one ketone $\left(\delta_{\mathrm{C}} 197.7\right)$, two ester carbons $\left(\delta_{\mathrm{C}} 172.0,170.2\right)$, one trisubstituted olefin carbon $\left(\delta_{\mathrm{C}} 153.2\right.$, $135.1)$, three oxymethine carbons $\left(\delta_{C} 76.8,65.3,64.6\right)$, eight methylenes, four methines, and seven methyl groups. In addition, the HMBC correlation from the singlet methyl at $\delta_{\mathrm{H}} 2.22$ to $\delta_{\mathrm{C}} 197.7$ suggested the presence of a methyl ketone moiety, instead of the lactone E-ring observed in compounds $\mathbf{1 - 4}$, leading to the conclusion that $\mathbf{5}$ had a B+F type skeleton, as shown in Figure 2.

Detailed interpretation of the combined spectral data of 5 revealed that the features related to the A-B-C ring system were identical to those of 1-4. As anticipated, the methyl ketone was positioned at $\mathrm{C}-17$ to form an unsaturated ketone in the $\mathrm{D}$ ring on the basis of $\mathrm{HMBC}$ correlations between $\mathrm{CH}_{3}-26\left(\delta_{\mathrm{H}} 2.22\right)$ and $\mathrm{C}-17\left(\delta_{\mathrm{C}} 135.1\right)$, and $\mathrm{H}-18\left(\delta_{\mathrm{H}} 6.72\right)$ and C-17/C-24 $\left(\delta_{\mathrm{C}} 197.7\right)$ (Figure 4$)$. Moreover, the ${ }^{1} \mathrm{H}-{ }^{1} \mathrm{H}$ COSY cross peak for $\mathrm{H}-14\left(\delta_{\mathrm{H}}\right.$ 1.76) $-\mathrm{H}_{2}-15\left(\delta_{\mathrm{H}} 1.89,1.61\right)-\mathrm{H}-16\left(\delta_{\mathrm{H}} 5.76\right)$ and $\mathrm{HMBC}$ correlations from $\delta_{\mathrm{H}} 2.02\left(\mathrm{C}_{3} \mathrm{CO}_{2}-\right)$ to $\delta_{\mathrm{C}} 170.2\left(\mathrm{CH}_{3} \mathrm{CO}_{2}-\right)$ and from $\mathrm{H}-16$ to $\delta_{\mathrm{C}} 170.2$ positioned an acetate substituent at $\mathrm{C}-16$, of which the relative configuration was assigned to be $\alpha$-orientation based on the small coupling constants between $\mathrm{H}_{2}-15$ and $\mathrm{H}-16\left(\mathrm{dd}, J_{\mathrm{H}-15-\mathrm{H}-16}=4.3,1.6 \mathrm{~Hz}\right)$.

Compound 6 was isolated as an amorphous solid. Its molecular formula was determined to be $\mathrm{C}_{30} \mathrm{H}_{46} \mathrm{O}_{5}$ by HRESIMS ( $m / z[\mathrm{M}+\mathrm{Na}]^{+} 509.3215$, calcd 509.3237), corresponding to eight degrees of unsaturation. The ${ }^{1} \mathrm{H}$ and ${ }^{13} \mathrm{C}$ NMR spectra obtained for compound $\mathbf{6}$ were almost identical to those of 5 . However, the absence of one ester carbon and the singlet methyl group at $\delta_{\mathrm{H}} 2.02$ suggested deacetylation from 5, which was further supported by an upfield shift of $\mathrm{H}-16\left(\delta_{\mathrm{H}} 4.62\right)$. The relative configuration of $\mathrm{OH}-16$ was assigned as $\beta$-orientation based on the large coupling constant observed between $\mathrm{H}-16$ and $\mathrm{H}-15 \beta\left(\mathrm{dd}, J_{\mathrm{H}-15-\mathrm{H}-16}=9.6,5.1 \mathrm{~Hz}\right)$.

Compound 7 was isolated as a yellow oil. Its molecular formula was determined to be $\mathrm{C}_{31} \mathrm{H}_{44} \mathrm{O}_{4}$ by HRESIMS ( $m / z[\mathrm{M}+\mathrm{Na}]^{+} 503.3113$, calcd 503.3132), corresponding to 10 degrees of unsaturation. Preliminary analysis of the ${ }^{1} \mathrm{H}$ and ${ }^{13} \mathrm{C}$ NMR data revealed that the scalarane-type scaffold had a cyclopropane substituent on the A ring. Interpretation of the ${ }^{13} \mathrm{C}$ NMR and HSQC spectra exhibited the $\mathrm{sp}^{2}$ carbons in the enone systems: three $\mathrm{sp}^{2}$ methines at $\delta_{\mathrm{H}} 7.38 / \delta_{\mathrm{C}} 157.5, \delta_{\mathrm{H}} 6.34 / \delta_{\mathrm{C}} 137.4$, and $\delta_{\mathrm{H}} 6.64 / \delta_{\mathrm{C}} 130.4$; and one trisubstituted $\mathrm{sp}^{2}$ carbon atom at $\delta_{\mathrm{C}} 136.4$. Therefore, $\mathrm{HMBC}$ correlations observed from $\mathrm{H}-25\left(\delta_{\mathrm{H}} 7.38\right)$ to $\mathrm{C}-17\left(\delta_{\mathrm{C}} 136.4\right) / \mathrm{C}-18\left(\delta_{\mathrm{C}} 49.3\right) / \mathrm{C}-24\left(\delta_{\mathrm{C}} 195.9\right), \mathrm{H}-26\left(\delta_{\mathrm{H}} 6.34\right)$ to C-17/C-24/C-25 $\left(\delta_{\mathrm{C}}\right.$ $157.5)$, and $\mathrm{H}-18\left(\delta_{\mathrm{H}} 3.35\right)$ to $\mathrm{C}-17 / \mathrm{C}-23\left(\delta_{\mathrm{C}} 14.5\right)$, as well as the ${ }^{1} \mathrm{H}-{ }^{1} \mathrm{H}$ COSY cross peak for $\mathrm{H}-18-\mathrm{H}-25-\mathrm{H}-26$, confirmed the presence of a $\triangle^{25,26}$-cyclopenten-24-one subunit for the E-ring and the trisubstituted double bond at $\triangle^{16,17}$ (Figure 4). 
Compound 8 was isolated as a yellow oil, and its molecular formula was determined to be $\mathrm{C}_{34} \mathrm{H}_{52} \mathrm{O}_{8}$ by HRESIMS $(\mathrm{m} / z \text { [M }+\mathrm{Na}]^{+} 611.3541$, calcd 611.3554), corresponding to nine degrees of unsaturation. The ${ }^{1} \mathrm{H}$ NMR spectrum obtained for compound 8 showed similar patterns to that of 5 . However, the upfield peaks observed for the cyclopropane moiety in 5 were substituted by an oxymethine at $\delta_{\mathrm{H}} 5.35$, a methyl singlet at $\delta_{\mathrm{H}} 1.09$, and an acetate at $\delta_{\mathrm{H}} 2.03$, suggesting the $\mathrm{C}+\mathrm{F}$ type scaffold shown in Figure 2. Therefore, the connectivity of C-27-C-20-C-4-C-19 was determined using the HMBC correlations observed from $\mathrm{CH}_{3}-19\left(\delta_{\mathrm{H}} 0.99\right)$ to $\mathrm{C}-20\left(\delta_{\mathrm{C}} 73.2\right)$ and from $\mathrm{CH}_{3}-27\left(\delta_{\mathrm{H}} 1.09\right)$ to $\mathrm{C}-4\left(\delta_{\mathrm{C}}\right.$ 39.4)/C-20 (Figure 6). In addition, the acetate at $\delta_{\mathrm{H}} 2.03$ exhibited a HMBC correlation with $\mathrm{C}-20$ to be located at $\mathrm{C}-20$. The relative configuration at $\mathrm{C}-20$ was assigned as $20 R^{*}$ from the NOESY correlations observed between $\mathrm{H}-20\left(\delta_{\mathrm{H}} 5.35\right)$ and $\mathrm{H}-2 \beta\left(\delta_{\mathrm{H}} 1.47\right) / \mathrm{CH}_{3}-22\left(\delta_{\mathrm{H}}\right.$ $0.87)$, and $\mathrm{H}-3 \beta\left(\delta_{\mathrm{H}} 1.67\right)$ and $\mathrm{CH}_{3}-27$ (Figure 7). Similarly, the configuration of the acetate group at $\mathrm{C}-16$ was assigned as $\alpha$-orientation based on the small coupling constant observed for $\mathrm{H}-16\left(\mathrm{dd}, J_{\mathrm{H}-15-\mathrm{H}-16}=4.3,1.6 \mathrm{~Hz}\right)$.
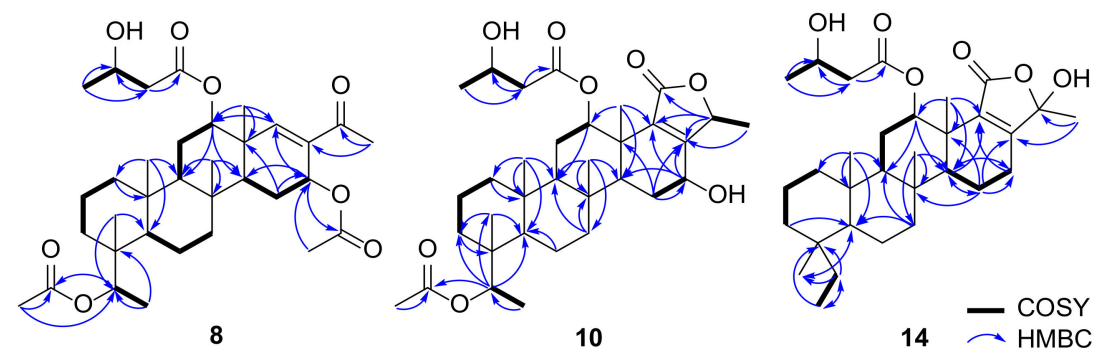

Figure 6. COSY and HMBC correlations observed for compounds 8, 10, and 14.

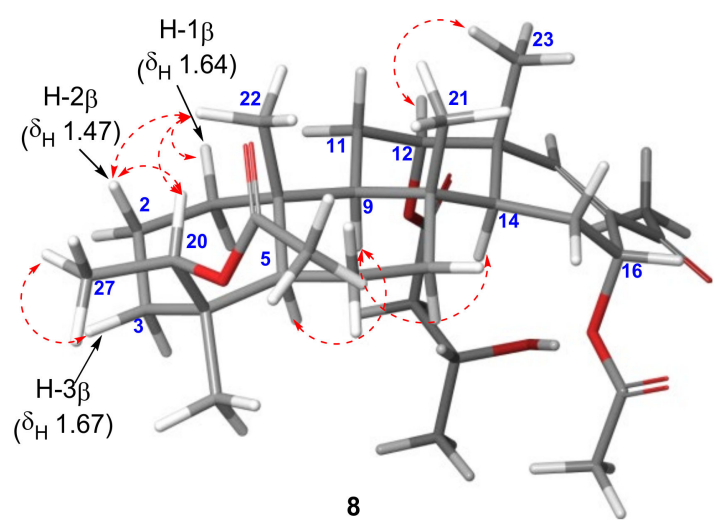

Figure 7. NOESY correlations observed for compound 8.

Compound 9 was isolated as a colorless oil, and its molecular formula was determined to be $\mathrm{C}_{30} \mathrm{H}_{48} \mathrm{O}_{6}$ by HRESIMS $\left(\mathrm{m} / z\left[\mathrm{M}+\mathrm{NH}_{4}\right]^{+}\right.$522.3810, calcd 522.3789) corresponding to seven degrees of unsaturation. Analysis of the 1D and 2D NMR data provided almost identical features to those of 8 to determine the carbon skeleton of compound $\mathbf{9}$. In this case, only one ester carbon atom $\left(\delta_{\mathrm{C}} 172.2\right)$ was observed in the ${ }^{13} \mathrm{C}$ NMR spectrum, and the acetate groups shown in the ${ }^{1} \mathrm{H}$ NMR spectrum of 8 disappeared. This information indicated that compound $\mathbf{9}$ was the deacetylation product of $\mathbf{8}$. Accordingly, the upfield shifts of $\mathrm{H}-20\left(\delta_{\mathrm{H}} 4.32\right)$ and $\mathrm{H}-16\left(\delta_{\mathrm{H}} 4.55\right)$ were the major differences, compared to compound 8.

Compound 10 was isolated as a yellow oil, and its molecular formula was determined to be $\mathrm{C}_{33} \mathrm{H}_{50} \mathrm{O}_{8}$ by HRESIMS ( $m / z$ [M $\left.+\mathrm{Na}\right]^{+}$597.3404, calcd 597.3398), corresponding to nine degrees of unsaturation. Preliminary inspection of the ${ }^{13} \mathrm{C}$ NMR and HSQC data of $\mathbf{1 0}$ identified four singlet methyl groups $\left(\delta_{\mathrm{H}} 0.87 / \delta_{\mathrm{C}} 16.6, \delta_{\mathrm{H}} 0.87 / \delta_{\mathrm{C}} 16.8, \delta_{\mathrm{H}} 0.96 / \delta_{\mathrm{C}} 23.3, \delta_{\mathrm{H}}\right.$ $\left.1.13 / \delta_{\mathrm{C}} 19.8\right)$, three doublet methyl groups $\left(\delta_{\mathrm{H}} 1.07 / \delta_{\mathrm{C}} 16.0, \delta_{\mathrm{H}} 1.18 / \delta_{\mathrm{C}} 22.5, \delta_{\mathrm{H}} 1.39 / \delta_{\mathrm{C}}\right.$ $18.2)$, and one acetate group $\left(\delta_{\mathrm{H}} 2.03 / \delta_{\mathrm{C}} 22.0\right)$, indicating a honulactone $\mathrm{C}$-like scaffold $\left(\mathrm{C}+\mathrm{D}\right.$ type shown in Figure 2) [12]. A detailed analysis of the ${ }^{1} \mathrm{H}$ NMR spectrum identified 
an oxymethine group at $\delta_{\mathrm{H}} 4.44$ as a major difference from honulactone $\mathrm{C}$. The location of the oxymethine was determined to be $\mathrm{C}-16$, as indicated by the HMBC correlations from $\mathrm{H}-16\left(\delta_{\mathrm{H}} 4.44\right)$ to $\mathrm{C}-17\left(\delta_{\mathrm{C}} 162.1\right) / \mathrm{C}-18\left(\delta_{\mathrm{C}} 135.6\right)$ and ${ }^{1} \mathrm{H}-{ }^{1} \mathrm{H}$ COSY cross peak for $\mathrm{H}_{2}-15$ $\left(\delta_{\mathrm{H}} 1.91,1.84\right)-\mathrm{H}-16$ (Figure 6$)$. The configuration of the $\mathrm{OH}-16$ group was assigned as $\alpha$-orientation based on the small coupling constant observed for $\mathrm{H}-16\left(\mathrm{dd}, \mathrm{J}_{\mathrm{H}-15-\mathrm{H}-16}=4.7\right.$, $1.4 \mathrm{~Hz}$ ), and compound 10 was named as $16 \alpha$-hydroxyhonulactone C [12].

Compound $\mathbf{1 1}$ was isolated as a yellow oil. Its molecular formula was determined as $\mathrm{C}_{33} \mathrm{H}_{50} \mathrm{O}_{8}$ by HRESIMS ( $m / z$ [M + Na $]^{+}$597.3396, calcd 597.3398), corresponding to nine degrees of unsaturation. The ${ }^{1} \mathrm{H}$ and ${ }^{13} \mathrm{C}$ NMR data of $\mathbf{1 1}$ were almost identical to those of 10, but a ketal moiety $\left(\delta_{C} 104.4\right)$ was observed instead of one doublet methyl group and two oxymethines in compound 10. As shown in compounds 2-4, the hemiketal functionality in the scalarane-type scaffold usually occurs at C-24 in the E-ring, which was also applicable in this case, as indicated by the HMBC correlations from $\mathrm{CH}_{3}-26\left(\delta_{\mathrm{H}} 1.56\right)$ to $\mathrm{C}-17\left(\delta_{\mathrm{C}}\right.$ $162.9) / \mathrm{C}-24\left(\delta_{\mathrm{C}} 104.4\right)$. The $\alpha$-orientation of the hydroxyl group at $\mathrm{C}-24$ was determined by the NOESY correlation between $\mathrm{H}-16 \beta\left(\delta_{\mathrm{H}} 2.33\right)$ and $\mathrm{CH}_{3}-26$. Thus, compound 11 was named $24 \alpha$-hydroxyhonulactone C [12].

Compound 12 was isolated as an inseparable mixture. Its molecular formula was determined as $\mathrm{C}_{33} \mathrm{H}_{48} \mathrm{O}_{8}$ by HRESIMS $\left(m / z[\mathrm{M}+\mathrm{Na}]^{+}\right.$595.3241, calcd 595.3241), corresponding to 10 degrees of unsaturation. Compared to 11, two more sp ${ }^{2}$ methines at $\delta_{\mathrm{C}}$ $138.9 / 138.7$ and $\delta_{\mathrm{H}} 6.38$, and $\delta_{\mathrm{C}} 118.44 / 118.35$ and $\delta_{\mathrm{H}} 6.28 / 6.26$ were observed in the ${ }^{13} \mathrm{C}$ NMR and HSQC spectra, indicating the presence of a disubstituted double bond. These $\mathrm{sp}^{2}$ protons were involved in a spin system for $\mathrm{H}-14\left(\delta_{\mathrm{H}} 2.66 / 2.62\right)-\mathrm{H}-15\left(\delta_{\mathrm{H}} 6.38\right)-\mathrm{H}-$ $16\left(\delta_{\mathrm{H}} 6.28 / 6.26\right)$ in the ${ }^{1} \mathrm{H}-{ }^{1} \mathrm{H}$ COSY spectrum and used to confirm the presence of the $\triangle^{15,16}$-olefin, which was further supported by HMBC correlations from H-15 to C-13 $\left(\delta_{\mathrm{C}}\right.$ $40.1 / 40.0) / \mathrm{C}-14\left(\delta_{\mathrm{C}} 53.96 / 53.90\right) / \mathrm{C}-17\left(\delta_{\mathrm{C}} 157.3\right)$ and from H-16 to C-14/C-18 $\left(\delta_{\mathrm{C}} 130.9\right)$. As discussed in the cases of 3 and 4 , the presence of the olefin at $\triangle^{15,16}$ and the hemiketal at C-24 rendered compound $\mathbf{1 2}$ an inseparable mixture of C-24 epimers.

Compound 13 was isolated as an amorphous solid. Its molecular formula was determined as $\mathrm{C}_{31} \mathrm{H}_{48} \mathrm{O}_{6}$ by HRESIMS ( $m / z[\mathrm{M}+\mathrm{Na}]^{+}$539.3325, calcd 539.3343), corresponding to eight degrees of unsaturation. Inspection of the ${ }^{1} \mathrm{H}$ NMR spectrum of 13 revealed most of the structural features of the bishomoscalarane-type skeletons. Precise analysis of the ${ }^{13} \mathrm{C}$ NMR and HSQC data revealed the presence of a triplet methyl group $\left(\delta_{\mathrm{H}} 0.67 / \delta_{\mathrm{C}} 8.80\right)$ and ketal carbon $\left(\delta_{C} 104.4\right)$, suggesting the $A+D$ type skeleton shown in Figure 2 . While most of the spectral data of $\mathbf{1 3}$ were identical to phyllofolactone $\mathrm{H}$, the ketal carbon indicated the oxidation of C-24 to give a 24-hydroxy pentenolide $\mathrm{E}$ ring. This insight can be confirmed by the HMBC correlation from $\mathrm{CH}_{3}-26\left(\delta_{\mathrm{H}} 1.48\right)$ to $\mathrm{C}-17\left(\delta_{\mathrm{C}} 163.0\right) / \mathrm{C}-24\left(\delta_{\mathrm{C}} 104.4\right)$. The configuration of $\mathrm{OH}-24$ was determined to be $\alpha$-orientation by the NOESY correlation between $\mathrm{H}-16 \beta\left(\delta_{\mathrm{H}} 2.33\right)$ and $\mathrm{CH}_{3}-26$. Thus, compound 13 was named $24 \alpha$-hydroxyphyllofolactone $\mathrm{H}[19]$.

Compound 14 was isolated as an inseparable mixture. Its molecular formula was determined as $\mathrm{C}_{31} \mathrm{H}_{46} \mathrm{O}_{6}$ by HRESIMS $\left(m / z[\mathrm{M}+\mathrm{Na}]^{+} 537.3175\right.$, calcd 537.3187), corresponding to nine degrees of unsaturation. Similar to compound 3 , the ${ }^{13} \mathrm{C}$ NMR spectrum of 14 showed a 1:1 splitting pattern corresponding to a mixture of two diastereomers. The distinctive spectral features of 14, differentiated from 13, were observed as the two $\mathrm{sp}^{2}$ methines at $\delta_{\mathrm{H}} 6.40 / 6.38$ and 6.28/6.27, suggesting an unsaturated derivative of 13 . The methines belonged in the ${ }^{1} \mathrm{H}-{ }^{1} \mathrm{H}$ COSY correlation for $\mathrm{H}-14\left(\delta_{\mathrm{H}} 2.68 / 2.62\right)-\mathrm{H}-15\left(\delta_{\mathrm{H}}\right.$ $6.40 / 6.38)-\mathrm{H}-16\left(\delta_{\mathrm{H}} 6.28 / 6.27\right)$ to identify the olefin at C-15 (Figure 6). In addition, 14 was determined to be a mixture of $\mathrm{C}-24$ epimers, considering the largest splitting observed at $\mathrm{CH}_{3}-26\left(\Delta \delta_{\mathrm{C}} 1.13 \mathrm{ppm}\right)$.

Compound $\mathbf{1 5}$ was isolated as an inseparable mixture. Its molecular formula was determined to be $\mathrm{C}_{32} \mathrm{H}_{48} \mathrm{O}_{6}$ by HRESIMS ( $m / z[\mathrm{M}+\mathrm{Na}]^{+} 551.3366$, calcd 551.3343), corresponding to nine degrees of unsaturation. The MS data indicated an additional methylene relative to 14, which was further supported by the change observed in the coupling pattern of the terminal methyl group of the side chain at C-12 from a doublet to triplet. The ${ }^{13} \mathrm{C}$ 
NMR and HSQC data identified the methylene group at $\delta_{\mathrm{H}} 1.51 / 1.25$ and $\delta_{\mathrm{C}} 29.5 / 29.4$, which were involved in the spin system for $\mathrm{H}_{2}-2^{\prime}-\mathrm{H}-3^{\prime}-\mathrm{H}_{2}-4^{\prime}-\mathrm{CH}_{3}-5^{\prime}$ in the ${ }^{1} \mathrm{H}-{ }^{1} \mathrm{H}$ COSY spectrum to confirm the presence of the 3-hydroxypentanoate side chain. The orientation of the ester at C-12 was assigned as $\alpha$ by the NOESY signal between H-12 $\left(\delta_{\mathrm{H}} 5.55 / 5.49\right)$ and $\mathrm{CH}_{3}-23\left(\delta_{\mathrm{H}} 1.06 / 1.05\right)$, as well as the small coupling constant observed for $\mathrm{H}-12(\mathrm{dd}$, $J=2.3,1.8 \mathrm{~Hz}$ ), to identify 12-epi-phyllactone D/E.

Interestingly, the identified structure was previously isolated as a mixture of C-24 epimers by $\mathrm{Li}$ et al. in 2007 [11], but our experimental ${ }^{13} \mathrm{C}$ NMR data showed some discrepancies with the previously reported data at C-9 $(\Delta 4.28 \mathrm{ppm}), \mathrm{C}-11(\Delta 2.7 \mathrm{ppm})$, C-12 $(\Delta 2.08 \mathrm{ppm}), \mathrm{C}-14(\Delta 4.46 \mathrm{ppm})$, and C-23 $(\Delta 4.35 \mathrm{ppm})$ (Figure $8 \mathrm{a})$. In addition, another identification of 12-epi-phyllactone D/E was reported by Andersen et al. in 2009 [13]. Although they acquired almost identical experimental NMR data with ours rather than those reported by $\mathrm{Li}$, the isolated compound was estimated to be same as $\mathrm{Li}^{\prime} \mathrm{s}$ without consideration of the differences in NMR data (Tables S17 and S18, Supplementary Materials). Therefore, we investigated the variations in ${ }^{13} \mathrm{C}$ chemical shifts depending on the orientation of the substituents at C-12.

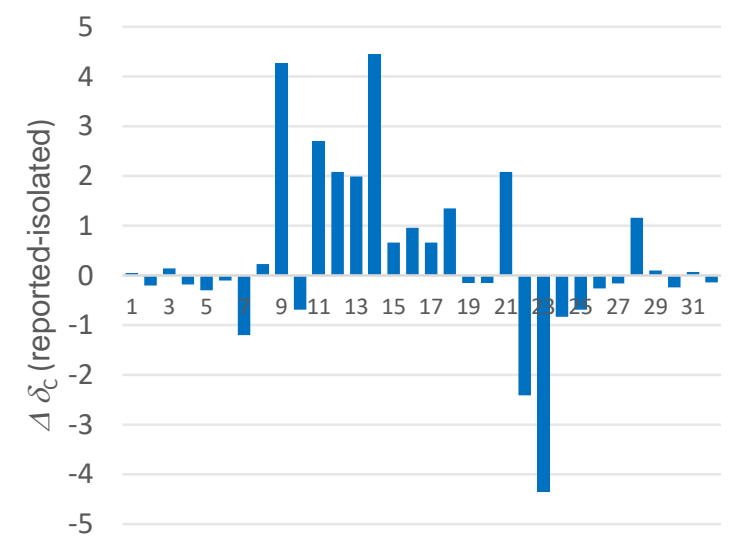

(a)

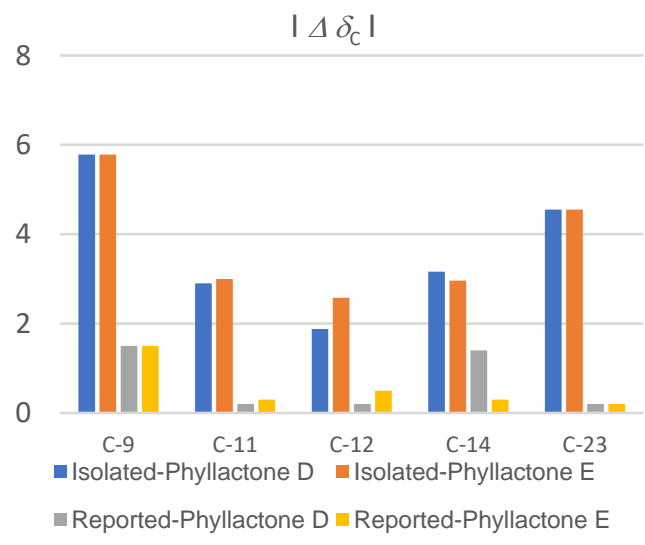

(b)

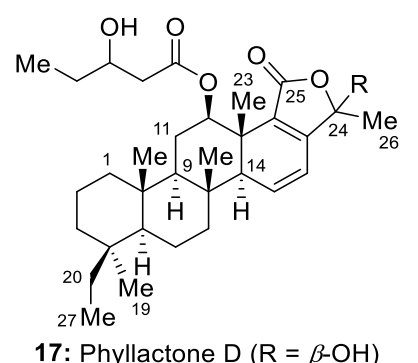

18: Phyllactone $\mathrm{E}(\mathrm{R}=\alpha-\mathrm{OH})$

(c)

Figure 8. (a) The differences observed between the experimental and reported ${ }^{13} \mathrm{C}$ chemical shifts (Li et al.) of 15 in $\mathrm{CDCl}_{3}$. (b) The deviations in the ${ }^{13} \mathrm{C}$ NMR chemical shifts observed for reported (Li et al.) and isolated 15 relative to phyllactone $\mathrm{D}$ and phyllactone $\mathrm{E}$. (c) The structures of phyllactone $\mathrm{D}$ and $\mathrm{E}$.

Phyllactone D (17) and E (18), the reported $12 \beta$-epimers of 15, were selected for comparison [25]. While C-12 in phyllactones D and E was observed at $\delta_{\mathrm{C}} 75.1$ and 75.8, 
respectively, the corresponding chemical shifts of the reported and isolated 15 were observed at $\delta_{\mathrm{C}} 75.3$ and 73.2/73.1, respectively. The deviations observed for isolated 15 from phyllactone D/E became more obvious at C-9, C-14, and C-23 (Figure 8b). However, the reported chemical shifts for $\mathbf{1 5}$ were better aligned with those of phyllactone D/E. Furthermore, the differences in the ${ }^{13} \mathrm{C}$ NMR chemical shifts observed between isolated 15 and compounds $3,4,12$, and 14, which share an identical substructure for the B-E ring system, showed negligible values $(<0.5 \mathrm{ppm})$ around the C-ring (Table S19, Supplementary Materials). Accordingly, isolated 15 is more likely to be the $12 \alpha$-epimer. Even though $\mathrm{Li}$ determined the 12a-configuration observing the NOESY signal between $\mathrm{H}-12$ and $\mathrm{CH}_{3}-23$ and $J_{\mathrm{H}-12-\mathrm{H}-13}$ calculation $(3.0,2.5 \mathrm{~Hz})$, the NMR database suggests that the compound previously reported by $\mathrm{Li}$ is presumed to be a mixture of phyllactone $\mathrm{D}(\mathbf{1 7})$ and $\mathrm{E}$ (18).

Compound 16 was isolated as a yellowish oil. Its molecular formula was determined as $\mathrm{C}_{27} \mathrm{H}_{40} \mathrm{O}_{5}$ by HRESIMS ( $m / z$ [M $+\mathrm{Na}^{+} 467.2762$, calcd 467.2768), corresponding to eight degrees of unsaturation. The ${ }^{1} \mathrm{H}$ NMR spectrum of $\mathbf{1 6}$ revealed five singlet methyl groups at $\delta_{\mathrm{H}} 0.73,0.74,0.79,0.85$, and 0.86 ; one acetate group at $\delta_{\mathrm{H}} 1.95$; one oxymethine at $\delta_{\mathrm{H}} 4.80$; one olefin at $\delta_{\mathrm{H}} 7.30$; and one aldehyde at $\delta_{\mathrm{H}} 9.41$. The ${ }^{13} \mathrm{C}$ and HSQC NMR spectra showed characteristic peaks for the aldehyde carbon atom at $\delta_{\mathrm{C}} 196.4$, two carbonyl carbons at $\delta_{\mathrm{C}} 169.6$ and 169.6, one trisubstituted olefin at $\delta_{\mathrm{C}} 145.8$ and 124.2, and one oxymethine at $\delta_{\mathrm{C}} 76.9$. The HMBC correlation between the two methyl groups at $\delta_{\mathrm{C}}$ 33.3 and 21.4 was identified as a characteristic feature of the 4-dimethyl-sesterterpenoid scaffold (Figure 9). The aldehyde at $\delta_{\mathrm{H}} 9.41$ exhibited a $\mathrm{HMBC}$ correlation with C-18 $\left(\delta_{\mathrm{C}}\right.$ $58.7)$ to be located at $\mathrm{C}-25$. Additional HMBC correlations from $\mathrm{H}-18\left(\delta_{\mathrm{H}} 3.07\right)$ to $\mathrm{C}-16$ $\left(\delta_{\mathrm{C}} 145.8\right) / \mathrm{C}-17\left(\delta_{\mathrm{C}} 124.2\right) / \mathrm{C}-24\left(\delta_{\mathrm{C}} 169.6\right)$, along with the ${ }^{1} \mathrm{H}-{ }^{1} \mathrm{H}$ COSY cross peak for $\mathrm{H}-14-\mathrm{H}_{2}-15-\mathrm{H}-16$, indicated the presence of the acid at C-24 and trisubstituted olefin at C-16. The acetate group $\left(\delta_{\mathrm{C}} 21.3 / \delta_{\mathrm{H}} 1.95\right)$ was positioned at $\mathrm{C}-12$, as indicated by the $\mathrm{HMBC}$ correlation from $\mathrm{H}-12\left(\delta_{\mathrm{H}} 4.80\right)$ to $\mathrm{C}-1^{\prime}\left(\delta_{\mathrm{C}} 169.6\right)$ and ${ }^{1} \mathrm{H}-{ }^{1} \mathrm{H}$ COSY cross peak for $\mathrm{H}_{2}-11-\mathrm{H}-12$. Thus, the planar structure of $\mathbf{1 6}$ was found to be the deacetalization product of scalarin (19) [3]. The NOESY correlations between $\mathrm{CH}_{3}-23\left(\delta_{\mathrm{H}} 0.86\right)$ and $\mathrm{H}-12 / \mathrm{H}-18$ determined the configuration of the $\mathrm{C}-12$ acetate and $\mathrm{C}-18$ formyl groups as $\alpha$.
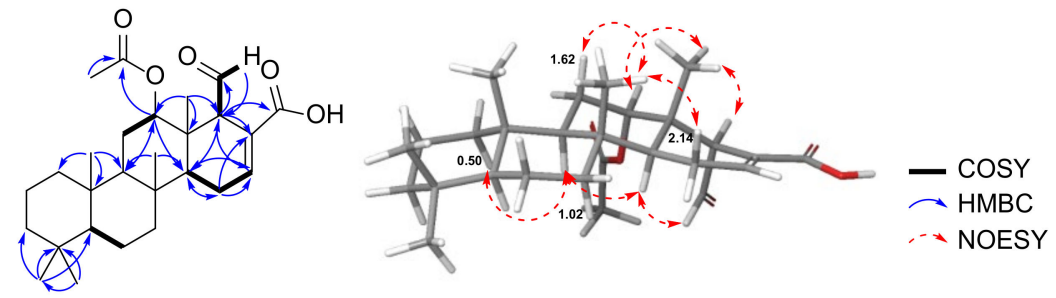

Figure 9. COSY, HMBC, and NOESY correlations observed for compound 16.

Whereas scalarin (19) exists only in its hemiacetal form, the formation of 18-epi-19 or 19 via the acetalization of $\mathbf{1 6}$ was not observed. To rationalize the observed difference in reactivity, 18-epi-16 was proposed as a plausible precursor of scalarin, and geometrical optimization of $\mathbf{1 6}$ and 18-epi-16 was performed at the B3LYP/6-31G** level of theory. The atomic distance between O-24 to C-25 was calculated to be $3.37 \AA$ for 16 and $2.68 \AA$ for 18-epi-16 (Figure 10). This result suggests that 18-epi-16 can undergo acetalization to form scalarin because the $\beta$-orientation of $\mathrm{C}-25$ increases its proximity to the acid at C-24. However, the acetalization of the $25 \alpha$-formyl group in $\mathbf{1 6}$ will be restricted due to its remoteness to $\mathrm{OH}-24$ to exist as its aldehyde form. 

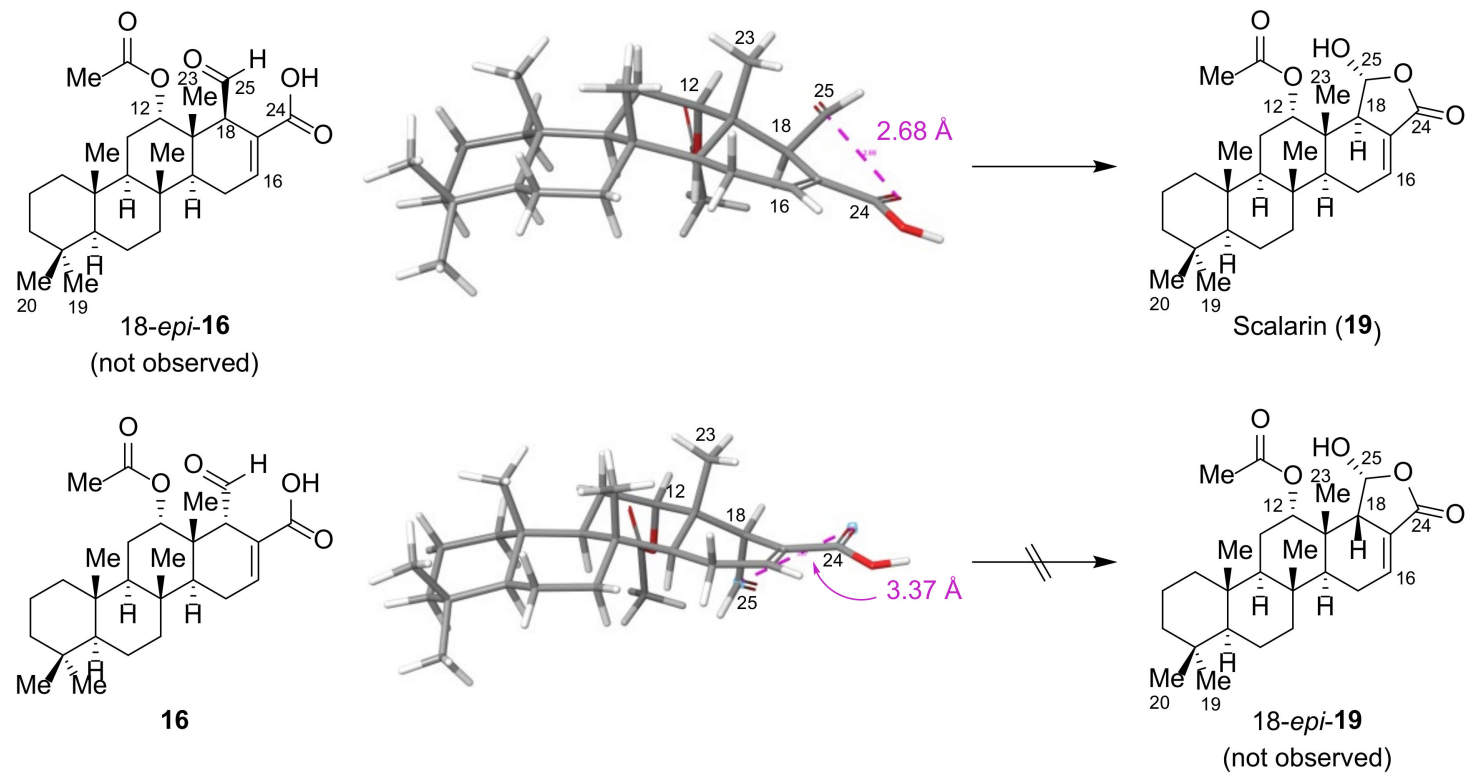

Figure 10. Atomic distances between O-24 and C-25 in compounds $\mathbf{1 6}$ and 18-epi-16.

\subsection{Biological Activity}

The cytotoxicity of compounds 1-16 against MDA-MB-231 (a human breast cancer cell line) was evaluated to elucidate their potential as anticancer agents. Compounds 1-6, 8, 11, and 13-15 exhibited moderate cytotoxicity with $\mathrm{GI}_{50}$ values ranging from 40 to $72 \mu \mathrm{M}$. Compounds 9, 10, 12, and 16 were inactive toward the cancer cell line (Table 1). Among the bishomoscalaranes, the highest anticancer activity was exhibited by compound 7, which has a relatively rare cyclopentenone E-ring (B+E type scaffold in Figure 2), with a $\mathrm{GI}_{50}$ value of $4.2 \mu \mathrm{M}$.

Table 1. The results of the cytotoxicity tests against MDA-MB-231 (human breast cancer cell line) obtained for compounds 1-16.

\begin{tabular}{ccccccccc}
\hline \multicolumn{7}{c}{ Cytotoxicity $^{\mathbf{1}}$ (MDA-MB-231) } \\
\hline Compound & $\mathbf{1}$ & $\mathbf{2}$ & $\mathbf{3}$ & $\mathbf{4}$ & $\mathbf{5}$ & $\mathbf{6}$ & $\mathbf{7}$ & $\mathbf{8}$ \\
\hline $\mathrm{GI}_{50}(\mu \mathrm{M})$ & 69.94 & 43.38 & 72.49 & 54.02 & 53.58 & 50.8 & 4.21 & 53.55 \\
\hline Compound & $\mathbf{9}$ & $\mathbf{1 0}$ & $\mathbf{1 1}$ & $\mathbf{1 2}$ & $\mathbf{1 3}$ & $\mathbf{1 4}$ & $\mathbf{1 5}$ & $\mathbf{1 6}$ \\
\hline $\mathrm{GI}_{50}(\mu \mathrm{M})$ & $>100$ & $>100$ & 71.14 & $>100$ & 50.71 & 63.54 & 40.82 & $>100$ \\
\hline
\end{tabular}

${ }^{1}$ Cisplatin (Sigma-Aldrich, St. Louis, MO) was used as a positive control $\left(\mathrm{GI}_{50}=1.31 \mu \mathrm{M}\right)$.

The highly diversified structures of the isolated scalaranes provided some information on their structure-activity relationship (SAR). The presence of the $\triangle^{15,16}$-olefin generally had a detrimental effect that reduced the cytotoxicity in the range of $12-30 \mu \mathrm{M}$, as shown by the sets of $\mathbf{2}$ and $\mathbf{3}$ (B+D type), 13 and $\mathbf{1 4}$ ( $\mathrm{C}+\mathrm{D}$ type), and $\mathbf{1 3}$ and $\mathbf{1 4}(\mathrm{A}+\mathrm{D}$ type). Comparing 3 with 4 and 14 with 15, the homologation of one methylene group at $C-4^{\prime}$ was beneficial toward increasing the activity to $\sim 20 \mu \mathrm{M}$. A series of compounds 2,11 , and 13 , which only differ at the C-4 substituent, indicated the disadvantageous effect of oxidation at C-20 on the anticancer activity. The negative effect of oxidation at C-20 was also observed in the inactive series of compounds $\mathbf{9 , 1 0}$, and $\mathbf{1 2}$.

\section{Materials and Methods}

\subsection{General Experimental Procedures}

Specific optical rotations were collected on a Rudolph Research Analytical (Autopol III) polarimeter (Rudolph Research Analytical, Hackettstown, NJ, USA). IR spectra were 
measured on a JASCO FT/IR-4100 spectrophotometer (JASCO Corporation, Tokyo, Japan). The 1D and 2D NMR spectra were taken in $\mathrm{CDCl}_{3}$ using a Bruker $600 \mathrm{MHz}$ spectrometer (Bruker BioSpin $\mathrm{GmbH}$, Rheinstetten, Germany) at $297.1 \mathrm{~K} .{ }^{1} \mathrm{H}$ NMR spectra were collected after 64-128 scans, and ${ }^{13} \mathrm{C}$ NMR spectra were collected at a range of 10,000-15,000 scans depending on the sample concentrations. The mixing time for NOESY experiments was set as $0.3 \mathrm{~s}$. Chemical shifts were reported in parts per million relative to $\mathrm{CHCl}_{3}$ residue $\left(\delta_{\mathrm{H}} 7.26, \delta_{\mathrm{C}} 77.1\right)$ in $\mathrm{CDCl}_{3}$. High resolution mass-spectra were obtained on a Sciex X500R Q-TOF spectrometer (Framingham, MA, USA) equipped with an ESI source. MPLC was performed using the TELEDYNE ISCO CombiFlash Companion with the TELEDYNE ISCO RediSep Normal-phase Silica Flash Column (Teledyne ISCO, Lincoln, NE, USA). HPLC was performed on a PrimeLine Binary pump (Analytical Scientific Instruments, Inc., El Sobrante, CA, USA) utilizing silica columns (YMC-Pack Silica, $250 \times 10 \mathrm{~mm}$ I.D., or $250 \times 4.6 \mathrm{~mm}$ I.D., 5 нm; YMC Co. Ltd., Kyoto, Japan), the Shodex RI-101 (Shoko Scientific Co. Ltd., Yokohama, Japan), or the UV-M201.

\subsection{Biological Material}

The marine sponge used in this study was collected in March 2016 from the Bohol province in the Philippines ( $9^{\circ} 43^{\prime} 31.39^{\prime \prime}$ E $124^{\circ} 32^{\prime} 19.86^{\prime \prime}$ ) at a depth of $15 \mathrm{~m}$ using scuba diving. The sponge was directly kept frozen at $-20^{\circ} \mathrm{C}$ until identified as Dysidea sp. and chemically analyzed. A voucher sample (163PIL-267) has been stored at the Marine Biotechnology Research Center, Korea Institute of Ocean Science \& Technology (KIOST).

\subsection{Extraction and Isolation}

The lyophilized specimen (wet wt. $1.5 \mathrm{~kg}$ ) was extracted with $\mathrm{MeOH}(2.0 \mathrm{~L} \times 3)$ and $\mathrm{CH}_{2} \mathrm{Cl}_{2}(4.0 \mathrm{~L} \times 2)$ at room temperature. The combined extracts were concentrated under reduced pressure. The dried residue $(89.5 \mathrm{~g})$ was partitioned with $n$-butanol $(5.0 \mathrm{~L})$ and water $(5.0 \mathrm{~L})$. The $n$-butanol layer was concentrated and further partitioned between $n$-hexane $(3.0 \mathrm{~L})$ and $15 \%$ aqueous methanol $(3.0 \mathrm{~L})$. A portion $(12.2 \mathrm{~g})$ of the concentrated $15 \%$ aqueous methanol fraction ( $31.7 \mathrm{~g}$ ) was subjected to flash column chromatography over C18 (YMC Gel ODS-A, $60 \AA$, 230 mesh (YMC Co, Ltd., Kyoto, Japan)) with a stepwise gradient solvent system $(50 \%, 60 \%, 70 \%, 80 \%, 90 \%$, and $100 \% \mathrm{MeOH}$, acetone, and EtOAc).

The $80 \% \mathrm{MeOH}$ fraction $(612.7 \mathrm{mg}$ ) was further separated using MPLC on C18 with a gradient solvent system from $70 \% \mathrm{MeOH}$ to $100 \% \mathrm{MeOH}$ over 40 minutes to yield 4 fractions. The third subfraction $(250.1 \mathrm{mg}$ ) was separated using HPLC (eluent $65 \%$ $\mathrm{MeOH})$ to yield $8\left(3.9 \mathrm{mg}, t_{\mathrm{R}}=38 \mathrm{~min}\right), \mathbf{9}\left(2.5 \mathrm{mg}, t_{\mathrm{R}}=42 \mathrm{~min}\right), \mathbf{1 0}\left(2.3 \mathrm{mg}, t_{\mathrm{R}}=58 \mathrm{~min}\right)$, honulactone C $(9.8 \mathrm{mg})$, and honulactone $\mathrm{D}(9.0 \mathrm{mg})$. The fourth subtractions $(175.3 \mathrm{mg})$ was separated using HPLC (eluent 70\% MeOH) to yield $\mathbf{1 1}\left(1.8 \mathrm{mg}, t_{\mathrm{R}}=28 \mathrm{~min}\right), \mathbf{1 2}(1.4 \mathrm{mg}$, $\left.t_{\mathrm{R}}=28 \mathrm{~min}\right)$, and honulactone $\mathrm{I}+\mathrm{J}$ mixture $(1.6 \mathrm{mg})$.

The $100 \% \mathrm{MeOH}$ fraction (4.22 g) was further separated using MPLC on C18 with a gradient solvent system from $30 \% \mathrm{MeOH}$ to $100 \% \mathrm{MeOH}$ over 40 minutes to yield 4 fractions. The second fraction ( $2.49 \mathrm{~g}$ ) was directly separated using MPLC on $\mathrm{SiO}_{2}$ with a gradient solvent system from $70 \% \mathrm{HX}$ to $100 \%$ EtOAc over 80 minutes to yield 8 subfractions (based on TLC analysis). Scalarin $(\mathbf{1 9}, 213.0 \mathrm{mg})$ was recrystallized from the second subfraction $(572.8 \mathrm{mg})$ under the HX-EtOAc solvent conditions. The residue ( $250.0 \mathrm{mg}$ ) of the second subfraction was separated using HPLC (HX/acetone $=7 / 1$ ) to yield $4\left(5.2 \mathrm{mg}, t_{\mathrm{R}}=54 \mathrm{~min}\right), 15\left(5.5 \mathrm{mg}\right.$, $\left.t_{\mathrm{R}}=48 \mathrm{~min}\right)$, phyllofolactone $\mathrm{H}(5.7 \mathrm{mg})$, and phyllofolactone I $(11.5 \mathrm{mg})$. The third subfraction $(295.5 \mathrm{mg})$ was separated using HPLC (HX/acetone $=7 / 1)$ to yield $\mathbf{1}\left(3.4 \mathrm{mg}, t_{\mathrm{R}}=34 \mathrm{~min}\right), \mathbf{3}\left(7.0 \mathrm{mg}, t_{\mathrm{R}}=76 \mathrm{~min}\right), \mathbf{1 4}(6.0 \mathrm{mg}$, $\left.t_{\mathrm{R}}=66 \mathrm{~min}\right), 13\left(2.3 \mathrm{mg}, t_{\mathrm{R}}=60 \mathrm{~min}\right), 16\left(4.5 \mathrm{mg}, t_{\mathrm{R}}=45 \mathrm{~min}\right.$, honulactone $\mathrm{A}(21.6 \mathrm{mg})$, honulactone $\mathrm{B}(26.2 \mathrm{mg})$, honulactone $\mathrm{E}+\mathrm{F}$ mixture $(21.4 \mathrm{mg})$, and phyllofolactone $\mathrm{J}+\mathrm{K}$ $(2.7 \mathrm{mg})$. The fourth subfraction $(380.0 \mathrm{mg})$ was separated using HPLC $(\mathrm{HX} /$ acetone $=5 / 1)$ to yield $2\left(3.1 \mathrm{mg}, t_{\mathrm{R}}=36 \mathrm{~min}\right), \mathbf{5}\left(1.6 \mathrm{mg}, t_{\mathrm{R}}=31 \mathrm{~min}\right), \mathbf{6}\left(5.6 \mathrm{mg}, t_{\mathrm{R}}=32 \mathrm{~min}\right), 7(5.0 \mathrm{mg}$, $\left.t_{\mathrm{R}}=30 \mathrm{~min}\right)$, and phyllofenone $\mathrm{C}(2.3 \mathrm{mg})$. 


\subsection{Assay}

Human breast cancer MDA-MB-231 cells were purchased from the American Type Culture Collection (ATCC, Manassas, VA, USA) and were cultured in Dulbecco's modified Eagle medium (DMEM) supplemented with 10\% fetal bovine serum (FBS, Gibco, Carlsbad, CA, USA), $1 \times$ antibiotic-antimycotic solution (Thermo Fisher Scientific, Waltham, MA, USA), and $25 \mathrm{mM}$ HEPES (Gibco). Cultures were maintained in a humidified atmosphere of $95 \%$ air $/ 5 \% \mathrm{CO}_{2}$ at $37^{\circ} \mathrm{C}$.

Cell viability was determined using a CCK-8 (Cell Counting Kit-8, Dojindo Laboratory, Kumamoto, Japan) assay according to the manufacturer's instructions. MDA-MB-231 cells were seeded at $5 \times 10^{3}$ cells/well into a 96-well plate and then were treated with various concentrations of compounds 1-16. Following treatment for $48 \mathrm{~h}$, the cells were incubated with the CCK-9 solution, and the absorbance was measured at $450 \mathrm{~nm}$ using a SpectraMax i3 microplate reader (Molecular Devices, Sunnyvale, CA, USA). GI 50 values were calculated from a non-linear regression fit using GraphPad Prism version 9.2.0 (GraphPad Software, La Jolla, CA, USA).

1: colorless oil; $[\alpha]_{\mathrm{D}}^{20}+20.0\left(\right.$ c 0.2, $\left.\mathrm{CHCl}_{3}\right) ; \mathrm{IR}$ (ATR) $v_{\max } 3131,2954,2929,2581,1770$, 1734, 1452, 1381, 1261, 1176, $1027 \mathrm{~cm}^{-1} ;{ }^{1} \mathrm{H}$ NMR and ${ }^{13} \mathrm{C}$ NMR, see Tables $\mathrm{S} 1$ and S2, Supplementary Materials; HRESIMS $m / z 523.3382[\mathrm{M}+\mathrm{Na}]^{+}$(calcd for $\mathrm{C}_{31} \mathrm{H}_{48} \mathrm{O}_{5} \mathrm{Na}$, 523.3394).

2: colorless oil; $[\alpha]_{\mathrm{D}}^{20}+40.0\left(\right.$ c 0.2, $\left.\mathrm{CHCl}_{3}\right) ; \mathrm{IR}(\mathrm{ATR}) v_{\max } 3735,2954,2925,2851,1731$, $1689,1452,1374,1278,1176,1014 \mathrm{~cm}^{-1} ;{ }^{1} \mathrm{H}$ NMR and ${ }^{13} \mathrm{C}$ NMR, see Tables S1 and S2, Supplementary Materials; HRESIMS $m / z 537.3167[\mathrm{M}+\mathrm{Na}]^{+}$(calcd for $\mathrm{C}_{31} \mathrm{H}_{46} \mathrm{O}_{6} \mathrm{Na}$, 537.3187).

3: colorless oil; $[\alpha]_{\mathrm{D}}^{20}+45.0\left(\right.$ c $\left.0.2, \mathrm{CHCl}_{3}\right) ;$ IR (ATR) $v_{\max } 3727,2957,2922,2865$, 2848, 1738, 1657, 1458, 1371, 1286, 1621, 1173, $1031 \mathrm{~cm}^{-1} ;{ }^{1} \mathrm{H}$ NMR and ${ }^{13} \mathrm{C}$ NMR, see Tables S1 and S2, Supplementary Materials; HRESIMS $m / z 535.3011[\mathrm{M}+\mathrm{Na}]^{+}$(calcd for $\left.\mathrm{C}_{31} \mathrm{H}_{44} \mathrm{O}_{6} \mathrm{Na}, 535.3030\right)$.

4: colorless oil; $[\alpha]_{\mathrm{D}}^{20}+48.3\left(\right.$ c $\left.0.2, \mathrm{CHCl}_{3}\right)$; IR (ATR) $v_{\max } 3735,2954,2922,2869,2855$, 1731, 1685, 1452, 1374, 1286, 1173, $1021 \mathrm{~cm}^{-1} ;{ }^{1} \mathrm{H}$ NMR and ${ }^{13} \mathrm{C}$ NMR, see Tables $\mathrm{S} 1$ and S2, Supplementary Materials; HRESIMS $m / z 549.3163[\mathrm{M}+\mathrm{Na}]^{+}$(calcd for $\mathrm{C}_{32} \mathrm{H}_{46} \mathrm{O}_{6} \mathrm{Na}$, 549.3187).

5: colorless oil; $[\alpha]_{\mathrm{D}}^{20}-20.0\left(c\right.$ 0.1, $\left.\mathrm{CHCl}_{3}\right)$; IR (ATR) $v_{\max } 3727,2961,2929,2851,1734$, 1678, 1452, 1367, 1254, 1173, $1027 \mathrm{~cm}^{-1} ;{ }^{1} \mathrm{H}$ NMR and ${ }^{13} \mathrm{C}$ NMR, see Tables S1 and S2, Supplementary Materials; HRESIMS $m / z 551.3310[\mathrm{M}+\mathrm{Na}]^{+}$(calcd for $\mathrm{C}_{32} \mathrm{H}_{48} \mathrm{O}_{6} \mathrm{Na}$, 551.3343).

6: amorphous powder; $[\alpha]_{\mathrm{D}}^{20}+45.0\left(c 0.2, \mathrm{CHCl}_{3}\right)$; IR (ATR) $v_{\max } 3735,2971,2929$, 2865, 1724, 1678, 1657, 1452, 1371, 1296, 1173, 1080, $1027 \mathrm{~cm}^{-1} ;{ }^{1} \mathrm{H}$ NMR and ${ }^{13} \mathrm{C}$ NMR, see Tables S1 and S2, Supplementary Materials; HRESIMS m/z $509.3215[\mathrm{M}+\mathrm{Na}]^{+}$(calcd for $\mathrm{C}_{30} \mathrm{H}_{46} \mathrm{O}_{5} \mathrm{Na}$, 509.3237).

7: colorless oil; $[\alpha]_{\mathrm{D}}^{20}+33.3\left(\right.$ c 0.1, $\left.\mathrm{CHCl}_{3}\right) ; \mathrm{IR}(\mathrm{ATR}) v_{\max } 3735,2957,2918,2848,1727$, 1702, 1657, 1458, 1371, 1254, 1176, $1038 \mathrm{~cm}^{-1} ;{ }^{1} \mathrm{H}$ NMR and ${ }^{13} \mathrm{C}$ NMR, see Tables S1 and S2, Supplementary Materials; HRESIMS $m / z 503.3113[\mathrm{M}+\mathrm{Na}]^{+}$(calcd for $\mathrm{C}_{31} \mathrm{H}_{44} \mathrm{O}_{4} \mathrm{Na}$, 503.3132).

8: colorless oil; $[\alpha]_{\mathrm{D}}^{20}+8.3\left(c 0.2, \mathrm{CHCl}_{3}\right)$; IR (ATR) $v_{\max } 3727,2961,2929,2851,1738$, 1721, 1671, 1505, 1452, 1374, 1246, $1031 \mathrm{~cm}^{-1} ;{ }^{1} \mathrm{H}$ NMR and ${ }^{13} \mathrm{C}$ NMR, see Tables S1 and S2, Supplementary Materials; HRESIMS $m / z 611.3541[\mathrm{M}+\mathrm{Na}]^{+}$(calcd for $\mathrm{C}_{34} \mathrm{H}_{52} \mathrm{O}_{8} \mathrm{Na}$, 611.3554).

9: colorless oil; $[\alpha]_{\mathrm{D}}^{20}-6.7$ (c 0.1, $\mathrm{CHCl}_{3}$ ); IR (ATR) $v_{\max } 2961,2925,2851,1745,1727$, 1505, 1265, $1031 \mathrm{~cm}^{-1} ;{ }^{1} \mathrm{H}$ NMR and ${ }^{13} \mathrm{C}$ NMR, see Tables S1 and S2, Supplementary Materials; HRESIMS $m / z 522.3810\left[\mathrm{M}+\mathrm{NH}_{4}\right]^{+}$(calcd for $\mathrm{C}_{30} \mathrm{H}_{52} \mathrm{NO}_{6}, 522.3789$ ).

10: colorless oil; $[\alpha]_{\mathrm{D}}^{20}+73.3\left(\mathrm{c}, 0.1, \mathrm{CHCl}_{3}\right)$; IR (ATR) $v_{\max } 3477,3388,2966,2923,2866$, 1729, 1457, 1368, $1250 \mathrm{~cm}^{-1} ;{ }^{1} \mathrm{H}$ NMR and ${ }^{13} \mathrm{C}$ NMR, see Tables S1 and S2, Supplementary Materials; HRESIMS $m / z$ 597.3404 [M + Na] $]^{+}$(calcd for $\mathrm{C}_{33} \mathrm{H}_{50} \mathrm{O}_{8} \mathrm{Na}$, 597.3398). 
11: colorless oil; $[\alpha]_{\mathrm{D}}^{20}+40.0\left(c 0.1, \mathrm{CHCl}_{3}\right)$; IR (ATR) $v_{\max } 2965,2918,2855,1731$, 1649, 1458, 1374, 1250, 1169, $1035 \mathrm{~cm}^{-1} ;{ }^{1} \mathrm{H}$ NMR and ${ }^{13} \mathrm{C}$ NMR, see Tables S1 and S2, Supplementary Materials; HRESIMS $m / z$ 597.3396 [M + Na] $]^{+}$(calcd for $\mathrm{C}_{33} \mathrm{H}_{50} \mathrm{O}_{8} \mathrm{Na}$, 597.3398).

12: colorless oil; $[\alpha]_{\mathrm{D}}^{20}+71.7\left(c 0.2, \mathrm{CHCl}_{3}\right) ;$ IR (ATR) $\nu_{\max } 3392,2946,2925,2858,1734$, 1455, 1367, 1243, $1180 \mathrm{~cm}^{-1} ;{ }^{1} \mathrm{H}$ NMR and ${ }^{13} \mathrm{C}$ NMR, see Tables S1 and S2, Supplementary Materials; HRESIMS $m / z$ 595.3241 [M + Na] $]^{+}$(calcd for $\mathrm{C}_{33} \mathrm{H}_{48} \mathrm{O}_{8} \mathrm{Na}$, 595.3241).

13: amorphous powder; $[\alpha]_{\mathrm{D}}^{20}+6.7\left(c 0.2, \mathrm{CHCl}_{3}\right)$; IR (ATR) $v_{\max } 3727,2957,2929$, 2848, 1727, 1657, 1455, 1374, 1278, $1176 \mathrm{~cm}^{-1} ;{ }^{1} \mathrm{H}$ NMR and ${ }^{13} \mathrm{C}$ NMR, see Tables S1 and S2, Supplementary Materials; HRESIMS $m / z 539.3325[\mathrm{M}+\mathrm{Na}]^{+}$(calcd for $\mathrm{C}_{31} \mathrm{H}_{48} \mathrm{O}_{6} \mathrm{Na}$, 539.3343).

14: colorless oil; $[\alpha]_{\mathrm{D}}^{20}+31.7\left(c\right.$ 0.2, $\left.\mathrm{CHCl}_{3}\right)$; IR (ATR) $v_{\max } 3717,2961,2925,2872,1727$, 1649, 1458, 1374, 1275, 1257, $1176 \mathrm{~cm}^{-1} ;{ }^{1} \mathrm{H}$ NMR and ${ }^{13} \mathrm{C}$ NMR, see Tables S1 and S2, Supplementary Materials; HRESIMS $m / z$ 537.3175 $[\mathrm{M}+\mathrm{Na}]^{+}$(calcd for $\mathrm{C}_{31} \mathrm{H}_{46} \mathrm{O}_{6} \mathrm{Na}$, 537.3187).

15: colorless oil; $[\alpha]_{\mathrm{D}}^{20}+30.0\left(c \quad 0.2, \mathrm{CHCl}_{3}\right)$; IR (ATR) $v_{\max } 3735,2957,2925,2869$, 1731, 1448, 1363, 1278, 1176, $1014 \mathrm{~cm}^{-1} ;{ }^{1} \mathrm{H}$ NMR and ${ }^{13} \mathrm{C}$ NMR, see Tables S1 and S2, Supplementary Materials; HRESIMS $m / z 551.3366[\mathrm{M}+\mathrm{Na}]^{+}$(calcd for $\mathrm{C}_{32} \mathrm{H}_{48} \mathrm{O}_{6} \mathrm{Na}$, 551.3343).

16: colorless oil; $[\alpha]_{\mathrm{D}}^{20}-70.0\left(c 0.2, \mathrm{CHCl}_{3}\right)$; IR (ATR) $v_{\max } 3727,2961,2922,2851$, 1738, 1646, 1452, 1381, 1225, $1021 \mathrm{~cm}^{-1} ;{ }^{1} \mathrm{H}$ NMR and ${ }^{13} \mathrm{C}$ NMR, see Tables S1 and S2, Supplementary Materials; HRESIMS $m / z 467.2762[\mathrm{M}+\mathrm{Na}]^{+}$(calcd for $\mathrm{C}_{27} \mathrm{H}_{40} \mathrm{O}_{5} \mathrm{Na}$, 467.2768).

\section{Conclusions}

A total of 15 novel scalaranes 1-14 and 16, including 14 bishomoscalaranes and one scalarin derivative, has been isolated from the marine sponge, Dysidea sp., and characterized using a combination of 1D and 2D NMR spectroscopy. The isolation and structural identification of compound 15 resulted in the reassignment of the previously characterized 12-epi-phyllactone D/E. The actual structure of the reported 12-epi-phyllactone D/E was determined to be a mixture of known phyllactones $\mathrm{D}$ and $\mathrm{E}$ through the precise analysis of the experimental and reported ${ }^{13} \mathrm{C}$ chemical shifts. In addition, the effect of the $\mathrm{C}-18$ configuration in $\mathbf{1 6}$ on the formation of the hemiacetal E-ring was rationalized by measuring the atomic distances between C-25 and O-24 in 16 and 18-epi-16. Finally, the evaluation of the anticancer activities of compounds 1-16 against MDA-MB-231 revealed that compound 7 exhibited significant cytotoxicity with a $\mathrm{GI}_{50}$ value of $4.2 \mu \mathrm{M}$. Detailed studies to elucidate the biological mechanism of $\mathbf{7}$ are currently underway in our laboratory.

Supplementary Materials: The following are available online at https: / www.mdpi.com/article/ 10.3390/md19110627/s1, I. Experimental procedure; Figure S1: Structures of known compounds isolated from Dysidea sp., Tables S1-S16: ${ }^{13} \mathrm{C} /{ }^{1} \mathrm{H}$ chemical shifts for 1-16, Figure S2: Key ${ }^{1} \mathrm{H}-{ }^{1} \mathrm{H}$ COSY, HMBC correlations of 1-16, Figure S3: Key NOESY correlations of 1-16, Tables S17-S19, Figures S4 and S5: Comparison of ${ }^{13} \mathrm{C} /{ }^{1} \mathrm{H}$ chemical shifts for $12 \beta$ epimer $(\mathbf{1 7}, \mathbf{1 8})$ and $12 \alpha$ epimer $(\mathbf{1 5})$ reported by Li et al., Andersen et al., and our experiment, II. Computational methods; Supporting Information II; Figures S-1-S-112: ${ }^{1} \mathrm{H}$ NMR, ${ }^{13} \mathrm{C}$ NMR, COSY, HSQC, HMBC, NOESY, and HRMS spectra of 1-16.

Author Contributions: A.-Y.S. worked on isolation and structure elucidation. A.S. and C.C. performed the biological evaluation. J.L. collected the marine sponge and supervised the whole research work. All authors have read and agreed to the published version of the manuscript.

Funding: This work was supported by grants from the Ministry of Ocean and Fisheries (PM62520) and the Korea Institute of Ocean Science and Technology (PE99921).

Institutional Review Board Statement: Not applicable.

Informed Consent Statement: Not applicable. 
Data Availability Statement: All data presented in this study are available from the corresponding author on reasonable request.

Acknowledgments: We are grateful to Young-A Kim at Hannam University for the helpful discussions on the identification of the marine sponge and Byungho Park at EMNI for the technical support on the quantum mechanical calculations performed in this study. We thank Wilfredo Campos at University of the Philippines Visayas (UPV) for requesting and receiving permission to collect the marine sponge.

Conflicts of Interest: The authors declare no conflict of interest.

\section{References}

1. Evidente, A.; Kornienko, A.; Lefranc, F.; Cimmino, A.; Dasari, R.; Evidente, M.; Mathieu, V.; Kiss, R. Sesterterpenoids with anticancer activity. Curr. Med. Chem. 2015, 22, 3502-3522. [CrossRef]

2. Pour, P.M.; Behzad, S.; Asgari, S.; Khankandi, H.P.; Farzaei, M.H. Sesterterpenoids. In Recent Advances in Natural Products Analysis; Elsevier: Amsterdam, The Netherlands, 2020; pp. 347-391.

3. Fattorusso, E.; Magno, S.; Santacroce, C.; Sica, D. Scalarin, a new pentacyclic C-25 terpenoid from the sponge Cacospongia scalaris. Tetrahedron 1972, 28, 5993-5997. [CrossRef]

4. Yang, X.; Shao, Z.; Zhang, X. Sesterterpenes from the Sponge Dysidea sp. Z. Naturforsch. B 2010, 65, 625-627. [CrossRef]

5. Wang, Q.; Sun, Y.; Yang, L.; Luo, X.; de Voogd, N.J.; Tang, X.; Li, P.; Li, G. Bishomoscalarane sesterterpenoids from the sponge Dysidea granulosa collected in the South China Sea. J. Nat. Prod. 2020, 83, 516-523. [CrossRef]

6. Chee, C.L.; Otero-Quintero, S.; Nicholas, G.M.; Bewley, C.A. Phyllolactones AE: New bishomoscalarane sesterterpenes from the marine sponge Phyllospongia lamellosa. Tetrahedron 2001, 57, 5731-5738. [CrossRef]

7. Zeng, L.; Fu, X.; Su, J.; Pordesimo, E.O.; Traeger, S.C.; Schmitz, F.J. Novel bishomoscalarane sesterterpenes from the sponge Phyllospongia foliascens. J. Nat. Prod. 1991, 54, 421-427. [CrossRef]

8. Zhang, H.J.; Tang, H.F.; Yi, Y.H.; Lin, H.W. Scalarane sesterterpenes from the Chinese sponge Phyllospongia foliascens. Helv. Chim. Acta 2009, 92, 762-767. [CrossRef]

9. Fu, X.; Zeng, L.; Su, J.; Schmitz, F.J. Phyllofolactones C and D, two new minor Homoscalarane Sesterterpenes from the Chinese sponge Phyllospongia foliascens. J. Nat. Prod. 1999, 62, 644-646. [CrossRef]

10. Ponomarenko, L.P.; Kalinovsky, A.I.; Stonik, V.A. New Scalarane-based Sesterterpenes from the Sponge Phyllospongia $m$ adagascarensis. J. Nat. Prod. 2004, 67, 1507-1510. [CrossRef]

11. Lan, W.J.; Li, H.J. New sesterterpenoids from the marine sponge Phyllospongia papyracea. Helv. Chim. Acta 2007, 90, 1218-1222. [CrossRef]

12. Jiménez, J.I.; Yoshida, W.Y.; Scheuer, P.J.; Lobkovsky, E.; Clardy, J.; Kelly, M. Honulactones: New bishomoscalarane sesterterpenes from the Indonesian sponge Strepsichordaia aliena. J. Org. Chem. 2000, 65, 6837-6840. [CrossRef]

13. Williams, D.E.; Hollander, I.; Feldberg, L.; Frommer, E.; Mallon, R.; Tahir, A.; van Soest, R.; Andersen, R.J. Scalarane-based sesterterpenoid RCE-protease inhibitors isolated from the Indonesian marine sponge Carteriospongia foliascens. J. Nat. Prod. 2009, 72, 1106-1109. [CrossRef]

14. Cao, F.; Wu, Z.-H.; Shao, C.-L.; Pang, S.; Liang, X.-Y.; de Voogd, N.J.; Wang, C.-Y. Cytotoxic scalarane sesterterpenoids from the South China Sea sponge Carteriospongia foliascens. Org. Biomol. Chem. 2015, 13, 4016-4024. [CrossRef]

15. Song, J.; Jeong, W.; Wang, N.; Lee, H.-S.; Sim, C.J.; Oh, K.-B.; Shin, J. Scalarane sesterterpenes from the sponge Smenospongia sp. J. Nat. Prod. 2008, 71, 1866-1871. [CrossRef]

16. Kwon, O.-S.; Kim, D.; Kim, C.-K.; Sun, J.; Sim, C.J.; Oh, D.-C.; Lee, S.K.; Oh, K.-B.; Shin, J. Cytotoxic scalarane sesterterpenes from the sponge Hyrtios erectus. Mar. Drugs 2020, 18, 253. [CrossRef]

17. Abdelaleem, E.R.; Samy, M.N.; Desoukey, S.Y.; Liu, M.; Quinn, R.J.; Abdelmohsen, U.R. Marine natural products from sponges (Porifera) of the order Dictyoceratida (2013 to 2019): A promising source for drug discovery. RSC Adv. 2020, 10, 34959-34976. [CrossRef]

18. Gonzalez, A.M. Scalarane sesterterpenoids. Curr. Bioact. 2010, 6, 178-206. [CrossRef]

19. Jiménez, J.I.; Yoshida, W.Y.; Scheuer, P.J.; Kelly, M. Scalarane-based sesterterpenes from an Indonesian sponge Strepsichordaia aliena. J. Nat. Prod. 2000, 63, 1388-1392. [CrossRef] [PubMed]

20. Zhang, X.; Xu, H.-Y.; Huang, A.-M.; Wang, L.; Wang, Q.; Cao, P.-Y.; Yang, P.-M. Antibacterial meroterpenoids from the South China Sea sponge Dysidea sp. Chem. Pharm. Bull. 2016, 64, 1036-1042. [CrossRef] [PubMed]

21. Lu, Y.; Zhao, M. Two highly acetylated sterols from the marine sponge Dysidea sp. Z. Naturforsch B 2017, 72, 49-52. [CrossRef]

22. Liu, L.; Wu, W.; Li, J.; Jiao, W.-H.; Liu, L.-Y.; Tang, J.; Liu, L.; Sun, F.; Han, B.-N.; Lin, H.-W. Two sesquiterpene aminoquinones protect against oxidative injury in HaCaT keratinocytes via activation of AMPK $\alpha$ /ERK-Nrf2/ARE/HO-1 signaling. Biomed. Pharm. 2018, 100, 417-425. [CrossRef] [PubMed]

23. Diaz-Marrero, A.R.; Austin, P.; Van Soest, R.; Matainaho, T.; Roskelley, C.D.; Roberge, M.; Andersen, R.J. Avinosol, a meroterpenoid-nucleoside conjugate with antiinvasion activity isolated from the marine sponge Dysidea sp. Org. Lett. 2006, 8 , 3749-3752. [CrossRef] [PubMed] 
24. Zhang, H.; Skildum, A.; Stromquist, E.; Rose-Hellekant, T.; Chang, L.C. Bioactive polybrominated diphenyl ethers from the marine sponge Dysidea sp. J. Nat. Prod. 2008, 71, 262-264. [CrossRef] [PubMed]

25. Fu, X.; Zeng, L.M.; Su, J.Y.; Pais, M.; Potier, P. Scalarane-type bishomosesterterpenes from the sponge Phyllospongia foliascens. J. Nat. Prod. 1992, 55, 1607-1613. [CrossRef] [PubMed]

26. Fu, X.; Zeng, L.; Su, J.; Pais, M.; Potier, P. Two new sesterterpenes from a South China sea sponge. J. Nat. Prod. 1993, 56, 1985-1988. [CrossRef] 